\title{
Plant growth regulators in the germination of Diospyros hispida A. DC. (EBENACEAE) seeds
}

\author{
Reguladores vegetais na germinação de sementes Diospyros hispida A. DC. (EBENACEAE) \\ Reguladores vegetales en la germinación de semillas de Diospyros hispida A. DC. (EBENACEAE)
}

Received: 01/29/2021 | Reviewed: 02/04/2021 |Accept: 02/08/2021 | Published: 02/15/2021

\author{
Aline Bueno Ramalho \\ ORCID: https://orcid.org/0000-0003-4246-7234 \\ Universidade Federal de Mato Grosso, Brasil \\ E-mail: nine_ramalho@hotmail.com \\ Lúcia Filgueiras Braga \\ ORCID: https://orcid.org/0000-0002-5776-1711 \\ Universidade do Estado de Mato Grosso, Brasil \\ E-mail: luciabraga@unemat.br
}

\begin{abstract}
Plant growth regulators in the germination of Diospyros hispida A. DC. (Ebenaceae) Seed. Diospyros hispida species is a native fruit that has long germination period, hindering seedling production. The aim of this work was to evaluate the germination of Diospyros hispida seeds under the effect of gibberellic acid and biostimulant applications. Four replicates of 25 seeds per treatment were used. Treatments were: T1 - distilled water, T2, T3 and T4 - GA 3 solutions at 100, 150 and $200 \mathrm{mg} \mathrm{L}^{-1}$, respectively, T5 - Immersion for 24 hours in distilled water with aeration, T6, T7 and T8 Immersion for 24 hours in aerated $\mathrm{GA}_{3}$ solutions at 100, 150 and $200 \mathrm{mg} \mathrm{L}-1$, respectively, T9, T10 and T11 -

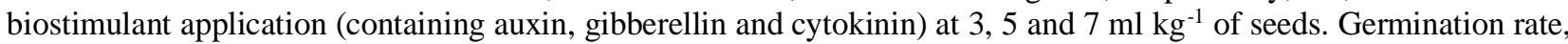
mean germination time, germination speed index, synchronization index, relative germination frequency, normal seedlings, root length, shoot length and seedling dry mass were evaluated. The effect of gibberellic acid and biostimulant containing auxin, gibberellin and cytokinin negatively influenced Diospyros hispida germination under the conditions of this study.
\end{abstract}

Keywords: Caqui-do-cerrado; Gibberellin; Biostimulant; Seed vigor.

\section{Resumo}

A espécie Diospyros hispida é uma frutífera nativa que possui longo período de germinação, dificultando a produção de mudas. Objetivou-se neste trabalho avaliar a germinação das sementes de Diospyros hispida sob efeito das aplicações de ácido giberélico e bioestimulante. Foram utilizadas quatro repetições de 25 sementes por tratamento. Os tratamentos foram: T1 - água destilada, T2, T3 e T4 - soluções de GA 3 a 100, 150 e $200 \mathrm{mg} \mathrm{L}^{-1}$, respectivamente, T5 - Imersão por 24 horas em água destilada com aeração, T6, T7 e T8 - Imersão por 24 horas em soluções aeradas de $\mathrm{GA}_{3}$ a 100, 150 e $200 \mathrm{mg} \mathrm{L}^{-1}$, respectivamente, T9, T10 e T11 - aplicação de bioestimulante (contendo auxina, giberelina e citocinina) a 3,5 e $7 \mathrm{~mL} \mathrm{~kg} \mathrm{de} \mathrm{sementes.} \mathrm{Avaliou-se} \mathrm{porcentagem} \mathrm{de} \mathrm{germinação,} \mathrm{tempo} \mathrm{médio} \mathrm{de}$ germinação, índice de velocidade de germinação, índice de sincronização, frequência relativa da germinação, plântulas normais, comprimento de raiz, comprimento de parte aérea e massa seca de plântula. O efeito do ácido giberélico e bioestimulante contendo auxina, giberelina e citocinina influenciou negativamente a germinação de Diospyros hispida nas condições deste estudo.

Palavras-chave: Caqui-do-cerrado; Giberelina; Bioestimulante; Vigor de sementes.

\section{Resumen}

La especie Diospyros hispida es un fruto autóctono que tiene un largo período de germinación, lo que dificulta la producción de plántulas. El objetivo de este trabajo fue evaluar la germinación de semillas de Diospyros hispida bajo el efecto del ácido giberélico y aplicaciones bioestimulantes. Se utilizaron cuatro repeticiones de 25 semillas por tratamiento. Los tratamientos fueron: T1 - agua destilada, T2, T3 y T4 - soluciones GA 3 a 100, 150 y 200 mg L-1, respectivamente, T5 - Inmersión por 24 horas en agua destilada con aireación, T6, T7 y T8 - Inmersión para 24 horas en soluciones aireadas de $\mathrm{GA}_{3}$ a 100,150 y $200 \mathrm{mg} \mathrm{L}^{-1}$, respectivamente, T9, T10 y T11 - aplicación de bioestimulante (que contiene auxina, giberelina y citoquinina) a 3,5 y $7 \mathrm{~mL} \mathrm{~kg} \mathrm{de} \mathrm{semillas.} \mathrm{Se} \mathrm{evaluó} \mathrm{porcentaje} \mathrm{de}$ germinación, tiempo promedio de germinación, índice de velocidad de germinación, índice de sincronización, frecuencia relativa de germinación, plántulas normales, longitud de raíz, longitud de brote y masa seca de plántula. El efecto del ácido giberélico y del bioestimulante que contiene auxina, giberelina y citoquinina influyó negativamente en la germinación de Diospyros hispida en las condiciones de este estudio. 
Palabras clave: Caqui-do-Cerrado; Giberelina; Bioestimulante; Vigor de la semilla.

\section{Introduction}

Diospyros hispida A. DC. is a small tree belonging to the Ebenaceae family, classified as deciduous, heliophytic and xerophytic, with reasonably heavy, soft, little resistant wood, subject to rot, tortuous and with dense crown (Lorenzi, 2016). Fruits are edible, have tannins, an astringent substance, and dispersion occurs in a zoochoric way by birds, monkeys and bats (Kuhlmann, 2012). According to Morais et al. (2012), the establishment of the species is predominantly favored in Cerrado regions, where edaphic restrictions are lower, as it offers greater nutrient availability and greater water retention capacity, thus, the physical and chemical soil properties influence the structure and spatial distribution of the species (Camilotti et al., 2011).

One of the problems found when considering the production of Diospyros hispida seedlings is the fact that seeds have long germination period, from 4 to 6 weeks (Lorenzi, 2016) with records of low germination percentage $(<30 \%)$ in a period 120 days of observation (Kuhlmann, 2012).

The natural mechanism of seeds to external factors imposed by the environment is called dormancy, that is, it is an essential event for the seed that may be related to the seed coat, embryo and due to the imbalance of germination inhibiting substances (Costa, et al., 2012).

Some substances known as plant growth regulators can improve seed germination and promote seedling growth (Peixoto, et al., 2011). Plant growth regulators are biologically active chemical or natural compounds, which can cease or decrease the impact of adverse factors on seed performance (Silva, et al., 2014). Depending on the mode of action, they act by stimulating the metabolism of hydrolytic enzymes that control cell division stages ( $\mathrm{O}^{\prime}$ brien, et al., 2010), leading to seed germination through overcoming dormancy (Külen, et al., 2011).

According to Dantas et al. (2012), during the initial stages of plant development, gibberellins promote root growth, allowing rapid recovery after water stress, increase resistance to insects, pests, diseases and nematodes and promote fast and uniform plant establishment, improving nutrient absorption and crop yield. Gibberellins are present in seeds as a broader spectrum hormone, as a promoter in a series of plant development processes, including seed germination, activating the embryo's vegetative growth, mobilizing endosperm reserves and acting in the weakening of the endosperm layer that surrounds the embryo, thus favoring growth (Taiz et al., 2017).

Growth regulating substances can act alone or in synergy with others (Prado-neto, et al., 2007). Currently, Stimulate $®$ biostimulant compound is available on the market, which is composed of $0.009 \%$ kinetin (cytokinin), $0.005 \%$ gibberellic acid (gibberellin) and $0.005 \%$ indolbutyric acid (auxin). This chemical increases plant growth and development, stimulates cell division, cell differentiation and elongation, and also increases nutrient absorption and utilization (Dantas, et al., 2012). The present study aimed to evaluate the germination of Diospyros hispida seeds under the effect of gibberellic acid and biostimulant applications (auxin, gibberellin and cytokinin).

\section{Methodology}

This article consists of a quantitative research, carried out through analyzes and periodicals after the application of plant regulators, with the objective of evaluating the effect of application of these regulators in the germination and formation of seedlings, as established by Pereira et al. (2018). For these authors, the collection of numerical data is performed through the collection of quantities and obtained through metrology, numbers with their units.

This work was carried out in the seedling nursery and Laboratory of Ecophysiology and Plant Propagation of the University of the State of Mato Grosso - UNEMAT, located at Campus I in Alta Floresta - MT, with geographical coordinates of $9^{\circ} 57^{\prime} 26.59$ "S latitude and $56^{\circ} 6^{\prime} 22.25$ "W longitude, and altitude of $283 \mathrm{~m}$ a.s.l. 
According to the Köppen classification, the climate is Am type, tropical monsoon, with average annual temperature close to $26^{\circ} \mathrm{C}$ and average annual precipitation of $3000 \mathrm{~mm}$. Rains are concentrated in the summer months (November to April) and the winter (May to October) is marked by a dry period (Alvares, et al., 2013).

Ripe Diospyros hispida fruits were harvested from 30 naturally occurring matrices in the municipality of Alta Floresta - MT, and taken to the laboratory for manual seed removal. Seeds were washed in running water over a sieve to promote friction and remove the aryl. Seeds were sterilized in $2 \%$ sodium hypochlorite for five minutes and washed in distilled water, before being submitted to treatments.

The experimental design was completely randomized with 11 treatments: T1 - distilled water, T2, T3 and T4 Vetec ${ }^{\circledR}$ gibberellic acid $\left(\mathrm{GA}_{3}\right)$ solutions with $90 \%$ active principle at concentrations of 100,150 and $200 \mathrm{mg} \mathrm{L}^{-1}$, respectively moistening the germitest paper, T5 - Immersion for 24 hours in distilled water with aeration, T6, T7 and T8 - Immersion for 24 hours in aerated $\mathrm{GA}_{3}$ solutions at 100, 150 and $200 \mathrm{mg} \mathrm{L}^{-1}$, respectively, T9, T10 and T11 - biostimulant application at concentrations of 3, 5 and $7 \mathrm{~mL} \mathrm{~kg}^{-1}$ of seeds. Four replicates of 25 seeds per treatment were used. Then, seeds were treated with Captan SC® fungicide (Captan) in the proportion of $0.5 \%$ the seed mass. The biostimulant used was Stimulate®, composed of $0.009 \%$ kinetin (cytokinin), $0.005 \%$ gibberellic acid (gibberellin), $0.005 \%$ indolbutyric acid (auxin) and $99.981 \%$ inert ingredients.

In treatments $\mathrm{T} 1$ to $\mathrm{T} 4$, seeds were sown on germitest paper moistened with distilled water and $\mathrm{GA}_{3}$ solutions at proportion of 2.5 times the dry paper mass.

In treatments $\mathrm{T} 5$ to $\mathrm{T} 8$, seeds were immersed for 24 hours in $300 \mathrm{~mL}$ of water or $\mathrm{GA}_{3}$ solution, with aeration promoted by oxygenation pump (Master Super II type 127v 150L / h). Then, seeds were sown on germitest paper moistened with distilled water at proportion of 2.5 times the dry paper mass.

Biostimulant was directly applied to seeds (previously weighed) in treatments T9 to T11, adding to volumes of 3, 5 and $7 \mathrm{~mL}$ of Stimulate ${ }^{\circledR}$, the amount of distilled water necessary to achieve in each treatment the final volume of $20 \mathrm{~mL}$ (amount of solution necessary to moisten the seed mass). Then, sowing was carried out on germitest paper, moistened with distilled water at proportion of 2.5 times the paper mass. Germination counting started at the same time, with zero time being the same for all treatments.

Paper rolls were kept in plastic bags in B.O.D. chambers under constant temperature of $25^{\circ} \mathrm{C}$, defined after pregermination test and 12-hour photoperiod. Evaluations were:

Germination rate - Four subsamples of 25 seeds were used, and evaluation criterion was the protrusion of the primary root with length equal to $2 \mathrm{~mm}$ (Rehman, et al., 1996). Evaluations were carried out during 30 days after the start of the test and calculations were according to Laboriau and Valadares (1976) using the formula below:

$$
\mathrm{G}(\%)=\left(\frac{N}{A}\right) * 100
$$

Where: $\mathrm{G}(\%)=$ germination rate; $\mathrm{N}=$ number of germinated seeds; $\mathrm{A}=$ total number of seeds

Germination speed index (GSI) - GSI was determined along with the germination test. The formula used was proposed by Maguire (1962) and presented below:

$$
G S I=\frac{N 1}{D 1}+\frac{N 2}{D 2} \ldots . .+\frac{N n}{D n}
$$

Where: GSI $=$ Germination Speed Index; $\mathrm{N}_{1: \mathrm{n}}=$ number of germinated seeds on day $1, \ldots ., \mathrm{n} ; \mathrm{D}_{1: \mathrm{n}}=$ days for germination to occur

Mean germination time (MGT) - MGT was determined by the equation proposed by Labouriau and Valadares (1976) and results expressed in days. 


$$
M G T=\frac{(\text { Eniti })}{\Sigma n i}
$$

Where: $\mathrm{ni}=$ number of seeds germinated per day; $\mathrm{Ti}=$ evaluation time after the start of the test.

Relative germination frequency - calculations were performed through the daily germination count, according to formula developed by Labouriau and Valadares (1976):

$$
F r=\frac{n i}{\Sigma n i}
$$

where: $\mathrm{Fr}=$ relative germination frequency; $\mathrm{ni}=$ number of seeds germinated per day; $\Sigma \mathrm{ni}=$ total number of germinated seeds Synchronization index - calculations were performed from the relative germination frequency according to formula developed by Labouriau and Pacheco (1978):

$$
\overline{\mathrm{E}}=\Sigma \text { Fr } \log 2 F r
$$

where: $\overline{\mathrm{E}}=$ synchronization index; $\mathrm{Fr}=$ relative germination frequency; $\log _{2}=\log$ base 2 .

Percentage of normal seedlings - calculated along with the germination test, considering normal seedlings those with root system, hypocotyl, epicotyl, cotyledonous leaves and primary leaf developed 30 days after the beginning of the germination test.

Shoot and root length - obtained with the aid of $0.01 \mathrm{~mm}$ precision digital caliper and calculated by dividing the total measurements by the number of seedlings evaluated by replicate, obtaining average values in $\mathrm{cm}$. For shoot length, the distance from the seedling collar to the stem apical meristem was measured, and the distance from the seedling collar to the apex of the main root.

Seedling dry mass - defined as the average mass, corresponding to the mass of each seedling per replicate, using oven with air circulation for drying, set at $65 \pm 3^{\circ} \mathrm{C}$ until reaching constant weight, weighing on $0.001 \mathrm{~g}$ precision scale, according to methodology of Nakagawa (1999).

Data were submitted to analysis of variance and the means were compared using the Tukey test at $5 \%$ probability level using the SISVAR software (Ferreira, 2011) with synchronization index being transformed into $(X+0.5)^{\wedge} 0.5$.

\section{Results and Discussion}

Treatments with distilled water and gibberellic acid in seeds (T1, T2, T3, T4, T5, T6, T7 and T8), provided the highest germination rate and speed values (from 80 to $91 \%$ and 0.80 to 0.91 , respectively) (Table 1), indicating that the form of $\mathrm{GA}_{3}$ application at the concentrations used did not influence the germination performance regardless of imbibition time even in water immersion or $\mathrm{GA}_{3}$ treatments. Prado-Neto et al. (2007) observed positive effect of gibberellic acid at concentrations of 100 to $150 \mathrm{~mL} \mathrm{~L}^{-1}$, and negative effect of biostimulant at concentration of $5 \mathrm{~mL} \mathrm{~L}^{-1}$ for the germination speed index in genipapo seeds (Genipa americana L.). The absorption of solutions by seeds must occur at rate that allows the repair and / or reorganization of membranes at appropriate levels to activate metabolism in phase I. In phase II, hormonal regulation of seeds occurs, in this case, the increase in growth regulator concentrations negatively affects the formation of meristems, in other cases, makes levels balanced, providing increase in plant growth. According to these authors, the presence of gibberellic acid at these concentrations occurred to promote the germination speed, and consequently the germination speed index and cell elongation.

The use of biostimulant in treatments T9, T10 and T11 did not favor seed germination, with reduction in values with increased concentration (Table 1). Stimulate ${ }^{\circledR}$ presents a synergistic effect due to the balanced presence of growth regulators; however, at high concentrations, it may cause an inhibitory effect. 
Table 1. Mean germination rate (G), mean germination time (MGT), germination speed index (GSI), synchronization index $(\overline{\mathrm{E}})$, normal seedlings (NS), shoot length (SL), root length (RL) and seedling dry mass (SDM) values of Diospyros hispida A. DC.

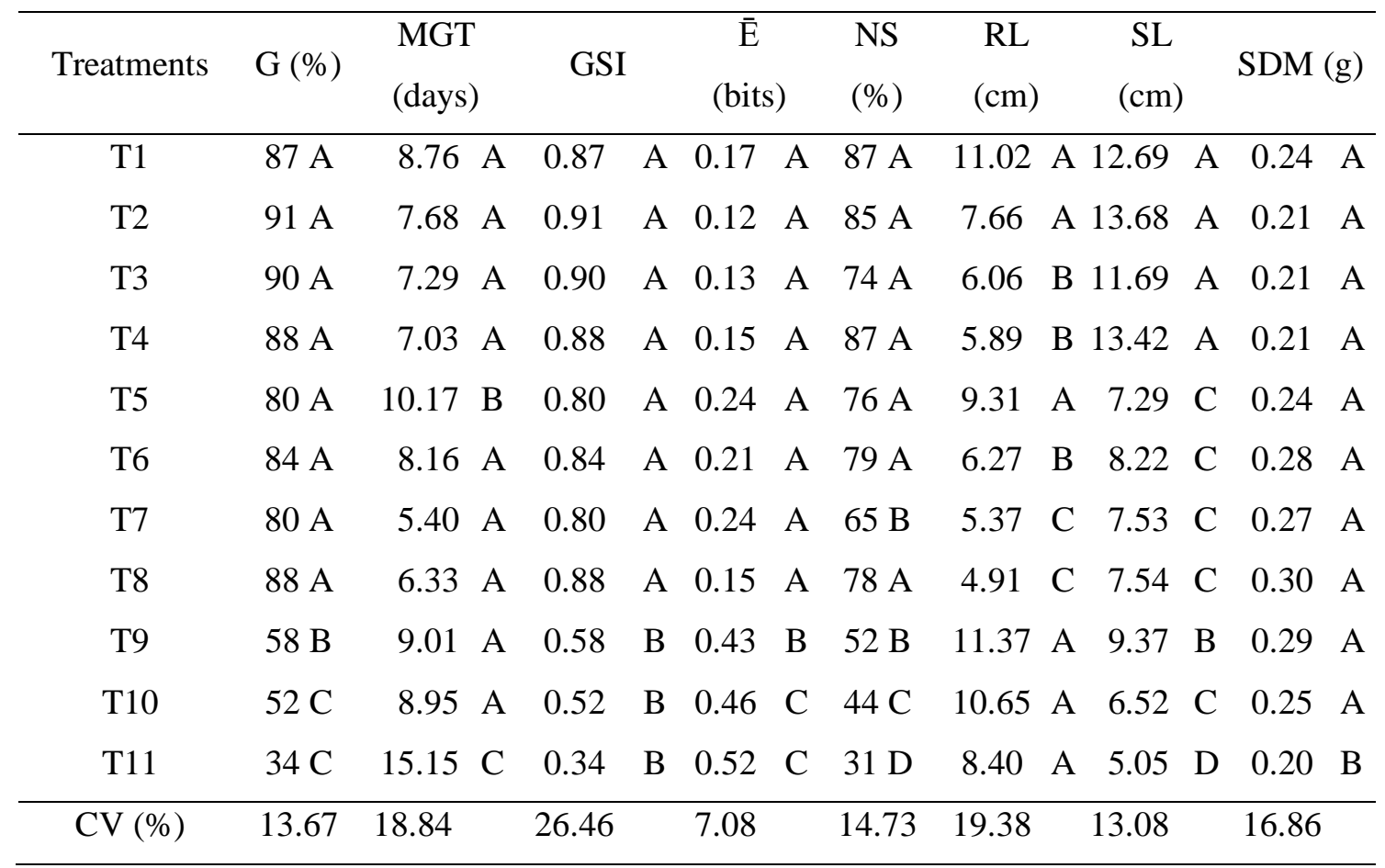

Means followed by the same letters in columns do not differ significantly by the Tukey's test at 5\% probability. T1 - distilled water, T2, T3 and T4 - gibberellic acid solutions $\left(\mathrm{GA}_{3}\right)$ at 100,150 and $200 \mathrm{mg} \mathrm{L}^{-1}$, respectively, T5 - Immersion for 24 hours in distilled water with aeration, T6, T7 and T8 - Immersion for 24 hours in aerated gibberellic acid (GA3) solutions at 100, 150 and $200 \mathrm{mg} \mathrm{L}^{-1}$, respectively, T9, T10 and T11 - application of biostimulant at concentrations of 3,5 and $7 \mathrm{~mL} \mathrm{~kg}^{-1}$ of seeds. Source: Authors (2020).

The imbibition of Diospyros hispida seeds in water or in $\mathrm{GA}_{3}$, regardless of the application method (on germitest paper or in aerated solution) provided better germination performance compared to the application of biostimulant.

The mean germination time (MGT) did not differ among treatments, except for T5 (previous imbibition of seeds for 24 hours in water with aeration) and $\mathrm{T} 11$ ( $7 \mathrm{~mL}$ of biostimulant $\mathrm{kg}^{-1}$ seeds). The mean time was affected by the process of immersion of seeds in water combined with aeration in treatment 5, resulting in greater water absorption. This result was observed by Rodrigues et al. (2012), who studied hydro-conditioning of lettuce (Lactuca sativa L.), which may be related to the volume of absorbed water, with consequent reflection on the increase in the time that seeds take to germinate. When aerated, water molecules have increased kinetic energy, increasing the imbibition pressure. In T11, toxicity was probably caused by the amount of product used, which may have decreased the performance of seeds in the germination process.

The highest values for the percentage of normal seedlings occurred in treatments with water and $\mathrm{GA}_{3}$ (74 to $87 \%$ ), except for $\mathrm{T} 7$, which differed significantly from the others, presenting $65 \%$ normal seedlings. Treatments with biostimulant showed the lowest values 31 to $52 \%$ ), results that can be attributed (Table 1) to the delayed germination with consequent increase in the occurrence of fungi and bacteria present in seeds during seedling development. The highest root length values were observed in treatments with distilled water without and with aeration for 24 hours (T1 and T5), $\mathrm{GA}_{3} 100 \mathrm{mg} \mathrm{L}^{-1}$ directly applied to the paper (T2) and in treatments with biostimulant (T9, T10 and T11). Peche et al. (2016) studied the effect of gibberellic acid on seeds of two species of the genus Diospyros and observed that $\mathrm{GA}_{3}$ at $100 \mathrm{mg} \mathrm{L}^{-1}$ increased the root length of D. kaki, whereas in D. lotus, it was observed that the increased gibberellic acid concentration reduced root length. PradoNeto et al. (2007) obtained better root growth results at biostimulant concentration of $10 \mathrm{~mL} \mathrm{~L}^{-1}$ for Genipa americana seeds. Dantas et al. (2012) in studies with Tamarind seeds (Tamarindus indica L.) found greater root increase with biostimulant 
concentration of $24 \mathrm{~mL} \mathrm{~L}^{-1}$, which is due to the synergistic effect of substances present in the growth regulator, improving the physiological process, promoting growth and initial development.

Shoot length showed significant differences among treatments, demonstrating that the process of previous imbibition with aeration of seeds for 24 hours (in water and $\mathrm{GA}_{3}$ ) negatively affected shoot formation; however, the opposite was observed in seedlings submitted to the effect of gibberellic acid or water directly applied on the paper (Table 1).

The effect of gibberellic acid and biostimulant was verified on root and shoot length. Treatment with distilled water and $\mathrm{GA}_{3}$ directly applied to the paper showed the best shoot length results, according to Dantas et al. (2012), $\mathrm{GA}_{3}$ remains active in cell division and elongation, promoting cell wall extensibility. $\mathrm{GA}_{3}$ concentrations of 50 and $100 \mu \mathrm{g} \cdot \mathrm{g}^{-1}$ positively favored shoot growth in watermelon seedlings (Citrullus lanatus (Thunb.) Matsum. \& Nakai), while $\mathrm{GA}_{3}$ concentration of 500 $\mu \mathrm{g} . \mathrm{g}^{-1}$ caused toxicity (Silva, et al., 2014). This effect was also verified by Santos et al. (2012) in passion fruit seedlings (Passiflora edulis Sims f. Flavicarpa Deg) from seeds pre-soaked in $\mathrm{GA}_{3}$ at concentration of $128 \mathrm{mg} \mathrm{L}^{-1}$. Diospyros hispida seeds suffered toxic effect of $\mathrm{GA}_{3}$ when combined with the aeration process, promoting reduction in shoot growth. The aeration process allowed the entry of more solutes in seeds and increased metabolism, probably causing hormonal imbalance. Vegetables have hormones in which the ideal balance for the growth of different plant organs is variable, and a given endogenous concentration can favor the growth of one organ and inhibit the growth of another. Biostimulant did not show positive results, causing shoot growth reductions with increased concentrations, but the opposite was verified in American Genipa seeds at concentrations of 5 and $10 \mathrm{~mL} \mathrm{~L}^{-1}$, with hypocotyl growth, not differing from gibberellic acid.

Only treatment T11 showed significant difference for seedling dry mass with lower value $(0.20 \mathrm{~g})$, compared to the other treatments (Table 1). The positive effect of gibberellic acid and biostimulant was verified on the dry mass of tamarind seedlings (Tamarindus indica L.) by Dantas et al. (2012).

The highest germination frequencies for treatments 1, 2, 3, and 4 (Figure 1 A, B, C and D) occurred between the first and the fifteenth day, with peaks ranging between the sixth and eighth day, followed by germination decreases. In treatment 5 (Figure 1A), the germination frequency was slower, extending throughout the evaluation period, while in treatment 6 (Figure 1B), the highest frequency was observed in the first days followed by decreases after 15 days. In treatments 7 and 8 (Figure 1C and D), peaks were observed on the third day, followed by rapid germination decrease. The germination frequency in treatment 9 (Figure 1E) was low and distributed up to 21 days, while in treatments 10 and 11, germination reduction was observed, extending throughout the evaluation period. The germination of seeds in contact with solution on paper occurred more frequently from the fifth day and with immersion in water and under aeration in the first days. According to results, the aeration process led to faster solution absorption, causing seeds to reach adequate levels in less time to start the germination process. Rodrigues et al. (2012) found that the germination frequency for lettuce did not change during the fourth and seventh evaluation days, both on paper and immersed under aeration. 
Figure 1. Relative germination frequency of Diospyros hispida A. DC seeds.

A

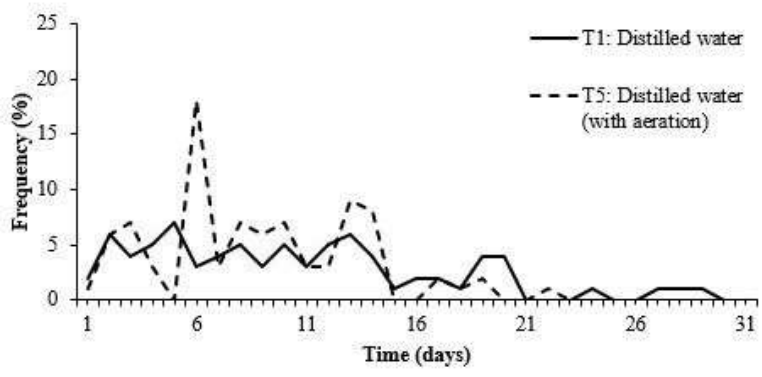

C

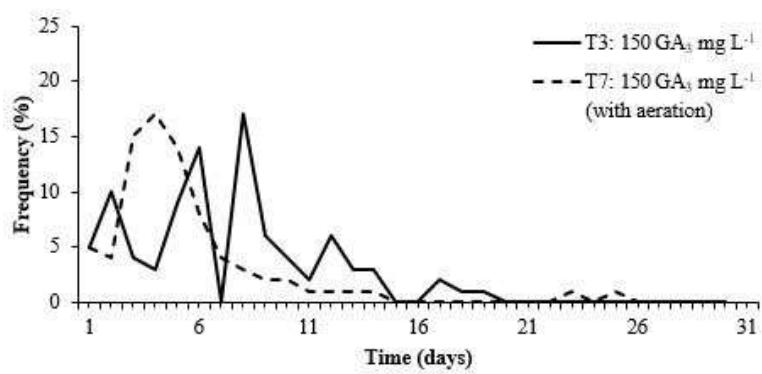

E

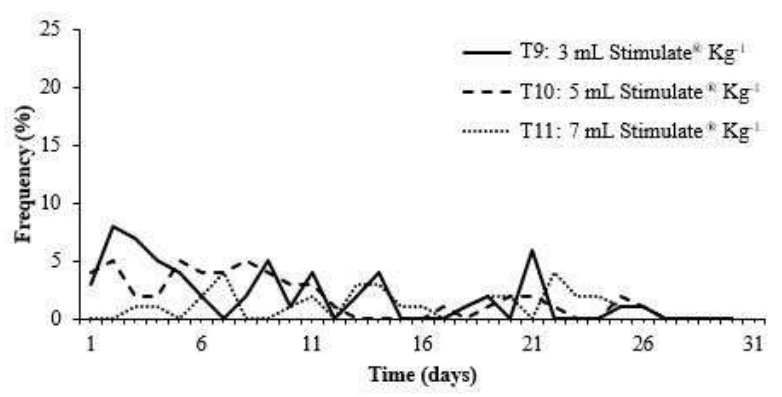

B

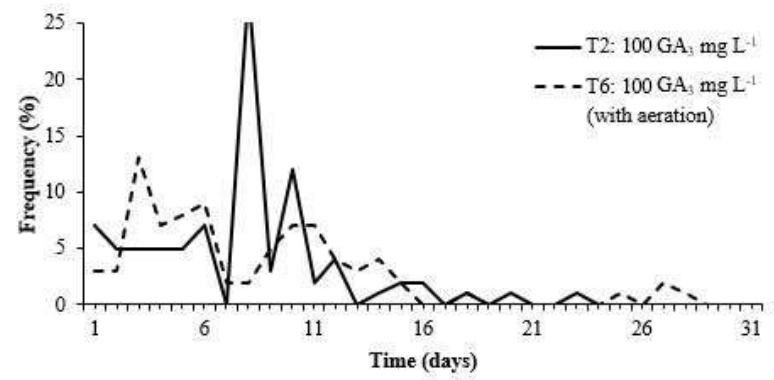

D

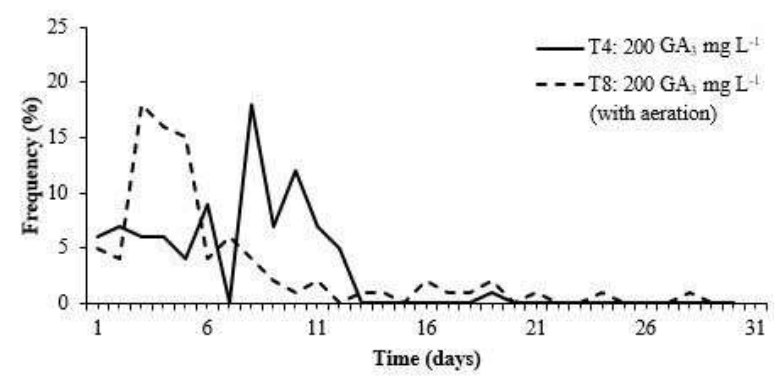

T1 - distilled water, T2, T3 and T4 - gibberellic acid (GA3) at 100, 150 and $200 \mathrm{mg} \mathrm{L}^{-1}$, respectively, T5 - Immersion for 24 hours in distilled water with aeration, T6, T7 and T8 - Immersion for 24 hours in aerated gibberellic acid (GA3) solutions at 100,150 and $200 \mathrm{mg} \mathrm{L}^{-1}$, respectively, T9, T10 and T11 - application of Stimulate at concentrations of 3,5 and $7 \mathrm{~mL} \mathrm{~kg}^{-1}$. Stimulate: auxin, gibberellin and cytokinin. Source: Authors (2020).

In the treatments with aeration, germination started earlier, with frequency peaks that extended throughout the evaluation period, however the highest germination frequencies occurred in treatments without aeration in the first 15 days after sowing. The biostimulant prolonged the relative frequency of germination until the end of the evaluation, with lower percentage values.

\section{Conclusion}

Diospyros hispida seeds aerated for 24 hours or without immersion in water or gibberellic acid showed high germination (80 to $91 \%$ ) and formation of normal seedlings (74 to $87 \%$ ).

The application of biostimulant containing auxin, gibberellin and cytokinin did not favor germination when compared to gibberellic acid for Diospyros hispida seeds.

The results of this study are promising to support future research on the use and application of other plant regulators on the imbibition process and the relationship with the germinative performance of Diospyros hispida seeds. 


\section{Acknowledgments}

This work was carried out with support from CNPq - National Council for Scientific and Technological Development - Brazil.

\section{References}

Alvares, C. A., Stape, J. L., Sentelhas, P. C., Moraes, G. de., Leonardo, J. \& Sparovek, G. (2013). Köppen's climate classification map for Brazil. Meteorologische Zeitschrift, 22(6), 711-728. 10.1127/0941-2948/2013/0507.

Camilotti, D. C., Pagotto, T. C. S. \& Araujo, A. C. (2011). Análise da vegetação arbórea de um remanescente de Cerradão em Bandeirantes, Mato Grosso do Sul, Brasil. Iheringia Série Botânica, 66(1), 31-46.

Costa, R. S., Oliveira, I, V, M., Môro, F, V. \& Martins, A. B. G. (2010). Caracterização morfológica do fruto, semente e morf ofunção de plântulas de sapoteira-preta (Diospyros ebenaster Retz.). Comunicata Scientiae, 1(1), 9-14.

Dantas, A. C. V. L., Queiroz, J. M. O., Vieira, E. L. \& Almeida, V. O. (2012). Effect of gibberellic acid and the bioestimulant Stimulate ${ }^{\circledR}$ on the initial growth of thamarind. Revista Brasileira de Fruticultura, 34(1), 008-014. 10.1590/S0100-29452012000100004.

Ferreira, D. F. (2011). SISVAR: a computer statistical analysis system. Ciência e Agrotecnologia, 35(6), 1039-1042. 10.1590/S1413-70542011000600001.

Kuhlmann, M. (2012). Frutos e sementes do Cerrado atrativos para fauna: guia de campo (2a ed.). Rede de Sementes do Cerrado.

Külen, O., Stushnoff, C., Davidson, R. D. \& Holm, D. G. M. (2011). Gibberellic acid and ethephon alter potato minituber bud dormancy and improve seed tuber yield. American Journal of Potato Research, 88(2), 167-174.

Labouriau, L. G. \& Pacheco, A. (1978). On the frequency of isothermal germination in seeds of Dolichos biflorus L. Plant and Cell Physiology, 19(3), 507512.

Labouriau, L. G. \& Valadares, M. E. B. (1976). On the germination of seeds Calotropis procera (Ait.) Ait.F. Anais da Academia Brasileira de Ciências, 48(2), 263-284. 10.1093/oxfordjournals.pcp.a075620

Lorenzi, H. (2016). Árvores brasileiras: Manual de identificação e cultivo de plantas arbóreas nativas do Brasil (2a ed.). Plantarum.

Maguire, D. (1962). Speed of germination-aind in selection and evaluation for seeddling emergence and vigour. Crop Science, 2(2), 176-177. 10.2135/cropsci1962.0011183X000200020033x.

Morais, R. F. D., Silva, E. C. S., Metelo, M. R. L. \& Morais, F. F. D. (2013). Composição florística e estrutura da comunidade vegetal em diferentes fitofisionomias do Pantanal de Poconé, Mato Grosso. Rodriguésia, 64(4), 775-790. 10.1590/S2175-78602013000400008.

Nakagawa, J. (1999). Testes de vigor baseados no desempenho de plântulas. In: Krzyzanowski F. C, Vieira, R. D, \& França Neto, J. B. (Eds.). Vigor de sementes: conceito e testes (Cap. 2, pp. 1-24). Londrina: ABRATES.

O'brien, R., Fowkes, N. \& Bassom, A. P. (2010). Models for gibberellic acid transport and enzyme production and transport in the aleurone layer of barley. Journal of Theoretical Biology, 267(1), 15-21. 10.1016/j.jtbi.2010.07.030.

Peche, P. M., Barbosa, C. M. de A., Pio, R., Sousa, P. H. \& Valle, M. H, do. (2016). Estratificação das sementes, ácido giberélico e temperatura na obtenção de porta-enxertos de caquizeiros. Revista Ciência Agronômica, 47(2), 387-39. 10.5935/1806-6690.20160046.

Peixoto, C. P., Sales, F. D. J. S., Vieira, E. L., Passos, A. R. \& Santos, J. M. D. S. dos. (2011). Ação da giberelina em sementes pré-embebidas de mamoneira. Comunicata Scientiae, 2(2), 70-75.

Pereira, A. S. et al. (2018). Metodologia da pesquisa científica. UFSM. https://repositorio.ufsm.br/bitstream/handle/1/15824/Lic_Computacao_Metod ologiaPesquisa-Cientifica.pdf?sequence $=1$.

Prado-Neto, M. P., Dantas, A. C. V. L., Vieira, E. L. \& Almeida, V. D. O. (2007). Germinação de sementes de jenipapeiro submetidas à pré-embebição em regulador e estimulante vegetal. Ciência e Agrotecnologia, 31(3) 693-698. 10.1590/S1413-70542007000300014.

Rehman, S., Harris, P. J. C., Bourne, W. F. \& Wilkin, J. (1996). The effects of sodium chloride on germinating and the potassium and calcium contents of Acacia seeds. Seed Science and Technology, 25(1), 45-57.

Rodrigues, D. L., Lopes, H. M., Silva, E. R. da. \& Silva, M. B. R. da. (2012). Embebição, condicionamento fisiológico e efeito do hipoclorito de sódio na germinação de sementes de alface. Revista Trópica: Ciências Agrárias e Biológicas, 6(1), 52-61. 10.0000/rtcab.v6i1.373.

Santos, C. A. C. dos., Vieira, E. L., Peixoto, C. P. \& Ledo, C. A. da S. (2012). Germinação de sementes e vigor de plântulas de maracujazeiro amarelo submetidos à ação do ácido giberélico. Bioscience Journal, 29(2), 400-407.

Silva, T., Silva, R., Silva, E., Santos, R., Aragão, C. \& Dantas, B. F. (2014). Germinação de sementes de melancia sob difere ntes métodos de tratamento com reguladores vegetais. Scientia Plena, 10(3), 1-6.

Taiz, L., Zeiger, E., Moller, I. M. \& Murphy, A. (2017). Fisiologia e desenvolvimento vegetal. (6a ed.). Artmed Editora. 